\title{
Parasite richness in fish larvae from the nearshore waters of central and northern Chile
}

\author{
Gabriela Muñoz ${ }^{1}$, Mauricio F. Landaeta ${ }^{2}$, Pamela Palacios-Fuentes ${ }^{2}$, Zambra López $^{3}$ and María Teresa González ${ }^{3}$ \\ ${ }^{1}$ Laboratorio de Parasitología Marina, Facultad de Ciencias del Mar y de Recursos Naturales, Universidad de Valparaíso, Valparaíso, \\ Chile; \\ ${ }^{2}$ Laboratorio de Ictioplancton (LABITI), Facultad de Ciencias del Mar y de Recursos Naturales, Universidad de Valparaíso, \\ Valparaíso, Chile; \\ ${ }^{3}$ Instituto de Ciencias Naturales ‘Alexander von Humboldt', Facultad de Ciencias del Mar y Recursos Biológicos, Universidad de \\ Antofagasta, Antofagasta, Chile
}

\begin{abstract}
In the present study, we determine the presence of parasites in fish larvae collected from nearshore waters along the northern and central coast of Chile. The parasites were identified to the lowest possible taxonomic level based on morphological and molecular analyses. The fish sample was composed of 5574 fish larvae. Of these, $3 \%$ harboured only larval ectoparasitic copepods whereas no endoparasites were found in the 1141 fish evaluated for this group of parasites. The parasitic copepods collected were initially classified as 'morphotypes' according to differences in morphological characteristics. They were then analysed using molecular techniques based on the $28 \mathrm{~S}$ and COI genes. Seven morphotypes of parasitic copepods (mostly at chalimus stages) were recognised: two of the morphotypes belonged to Pennellidae Burmeister, 1835, three to Caligidae Burmeister, 1835 and two were not identified. Only five morphotypes of copepods were analysed using molecular sequences, which confirmed the existence of six species: two pennellids of the genus Trifur Wilson, 1917 and two caligids of the genus Caligus Müller, 1785, plus two additional species that were morphologically different from these taxa. The pennellids were present in several fish species, being generally more prevalent than the caligids, in both the central and northern localities of Chile. Multispecies infections in larval fish were infrequent $(<1 \%)$. We conclude that fish larvae were rich in parasites, considering that these hosts exhibited small body sizes and were very young. We suggest that fish larvae could play a role, as intermediate hosts, in the life cycle of the parasitic copepods found.
\end{abstract}

Keywords: copepods, Pennellidae, Caligidae, fish larva assemblage, intertidal fish

Parasites are ubiquitous organisms found in a great diversity of hosts, including those in early stages of development. However, studies on parasites in young hosts are scarce and methods for the identification of these parasites are poorly developed because when larval hosts harbour parasites, they are generally also larval stages. In these stages, small morphological differences between species are observed and the specimens have no reproductive organs developed, making their identification difficult (e.g. Cribb et al. 2000). In these cases, molecular markers have been considered to be powerful tools in taxonomy, systematics and phylogeny, allowing researchers to assess whether morphological variations correspond to different species or to the same species with different phenotypes (Hebert et al. 2004, Radulovici et al. 2010).

Larval fish are abundant components of coastal systems (Moyano et al. 2009, Sutherland et al. 2012, Landaeta et al. 2013). They are characterised by body sizes, immune conditions and morphologies undergoing progressive develop- ment, which makes them highly vulnerable to environmental conditions, predation and parasites. Studies assessing parasites in fish larvae have identified copepods (Rosenthal 1967, MacKenzie 1974, Herrera 1984, 1990, Felley et al. 1987, Nielson et al. 1987, Palacios-Fuentes et al. 2012), digeneans (Balbuena et al. 2000, Cribb et al. 2000, Sirois and Dobson 2000, Bourque et al. 2006, Skovgaard et al. 2011) and nematodes (Rosenthal 1967, Skovgaard et al. 2011). Most of these groups of parasites are larval stages and only one such study identified an adult acanthocephalan (Lacerda et al. 2009). It is possible that fish larvae are better suited to tolerate larval stages that are less demanding for energetic resources than adult parasitic stages.

Fish larvae are characterised by showing low parasite burdens and a large fish sample is therefore needed to survey most of the parasite diversity in these hosts. Low parasite species richness (1-3 species) and intensity (1-4 parasites/fish) are fairly common in fish larvae, although the prevalence of parasites can be highly variable (5-70\%) 
(Sirois and Dobson 2000, Bourque et al. 2006, Skovgaard et al. 2011, Palacios-Fuentes et al. 2012). Copepods belonging to the family Caligidae Burmeister, 1835 have been found in several fishes, such as the anchovy (Engraulis ringens Jenyns) and the clingfish (Gobiesox marmoratus Jenyns) (Herrera 1984, 1990), with prevalence ranging between $1 \%$ and $16 \%$. Recently, copepods of the family Pennellidae Burmeister, 1835 were recorded in larval $\mathrm{Hel}$ cogrammoides chilensis (Cancino), showing prevalence between 3\% and 21\% (Palacios-Fuentes et al. 2012).

We aimed to identify all parasites (both ecto- and endoparasites) present in a nearshore assemblage of fish larvae off the coast of Chile. We identified the parasite species using morphological and molecular analyses and determined parasite loads for each fish species.

\section{MATERIALS AND METHODS}

We sampled larval fish along the northern and central coasts of Chile, at Antofagasta (Coloso: $23^{\circ} 45^{\prime} \mathrm{S} ; 70^{\circ} 28^{\prime} \mathrm{W}$ ) and Valparaíso (El Quisco: $33^{\circ} 24^{\prime} \mathrm{S} ; 71^{\circ} 43^{\prime} \mathrm{W}$ ) during the late austral winter and spring of 2012 and 2013. Sampling was conducted in the nearshore region $(<500 \mathrm{~m}$ offshore $)$ at twilight and at night (19:00-23:00 h), onboard an artisanal vessel. Oblique hauls of a Bongo net (with two conical nets, $60 \mathrm{~cm}$ diameter with a $300 \mu \mathrm{m}$ mesh size) were performed for 10-15 min at a depth of $20 \mathrm{~m}$. The volume of seawater filtered by the net was measured by a flow metre TSK (Tsurumi-Seiki Co., Ltd., Yokohama, Japan) placed inside the net during sampling. The water volume varied between 13 and $437 \mathrm{~m}^{3}$ (mean \pm standard deviation: $142 \pm 103 \mathrm{~m}^{3}$ ) depending on the vessel speed and duration of haul. The nets were subsequently washed onboard. The samples of one net were initially fixed with $5 \%$ formalin buffered with sodium borate and preserved in $96 \%$ ethanol after $12 \mathrm{~h}$; the sample of the other net was fixed in $96 \%$ ethanol for further molecular analyses.

All collected fish larvae were separated, counted and identified to the lowest possible taxonomic level following Balbontín and Pérez (1979), Pérez (1979, 1981), Herrera (1984) and Herrera et al. (2007). Fish were measured using a 5.0 MPx Moticam 2500 (Motic Instrument, Inc., Richmond, British Columbia, Canada) connected to an Olympus SZ-61 stereomicroscope (Olympus Corporation, Shinjuku-ku, Tokyo, Japan) and Motic Images Plus 2.0 software (Motic China Group, Co., Xiamen, China). Body length (BL) of each fish was measured to the nearest $0.01 \mathrm{~mm}$ from the tip of the upper maxilla to the tip of the notochord, in preflexion larvae (notochord length), or to the base of the hypurals, in flexion and postflexion larvae (standard length).

\section{Parasite morphology}

Fish were surveyed for parasites, considering metazoans only, excluding unicellular organisms. All fish larvae were assessed for ectoparasites on their body surface, fins and gills. Additionally, a total of 1141 fish larvae collected off Antofagasta (adding samples from Mejillones; $23^{\circ} 05^{\prime} \mathrm{S} ; 70^{\circ} 27^{\prime} \mathrm{W}$ ) and Valparaíso (adding samples from Montemar; $32^{\circ} 58^{\prime} \mathrm{S} ; 7^{\circ} 29^{\prime} \mathrm{W}$ ) were assessed for endoparasites by examining the muscles, brain, body cavity and digestive tract. Parasites were fixed in $96 \%$ ethanol, identified based on morphological characteristics and classified as different 'morphotypes'. From all parasites collected, 34 specimens were observed under an optical microscope for characterisation in terms of their body shape, buccal structures, legs, genital complexes and abdomen. All measurements are in micrometres $(\mu \mathrm{m})$ unless otherwise indicated. Initially, parasitic copepods were determined as belonging to the families Pennellidae and Caligidae according to their morphological characteristics (Kabata 1979, Castro and Baeza 1986, Brooker et al. 2007, Madinabeitia and Nagasawa 2011, Ismail et al. 2013, Venmathi-Maran et al. 2013). Two morphotypes (MT1 and MT7) belonged morphologically to the family Pennellidae, three morphotypes to the family Caligidae (MT2, MT5 and MT6) and two morphotypes (MT3 and MT4) were unidentified to the family level. The morphotype number of the parasites was assigned according to the order of their appearance during the assessment of the fish samples.

Morphological distinctions of the parasites were considered. For this purpose, the copepods were cleared with lactophenol during 2-5 min and observed under an optical microscope to register the morphometric and morphological characteristics. Drawings were produced using a camera lucida attached to a Leica DMLS2 light microscope. Some specimens of Caligidae $(n=5)$, Pennellidae $(\mathrm{n}=8)$ and one undetermined copepod $(\mathrm{n}=1$ MT3) were also observed via scanning electron microscopy (SEM), although the most infrequent copepods (MT4 and MT5) were not observed through SEM because there were insufficient specimens for this purpose. The copepods were dehydrated through an ethanol series $(70-100 \%)$, followed by critical point drying in $\mathrm{CO}_{2}$ using a Samdri-780A machine (Tousimis Research Corporation, Rockville, MD, USA), sputter-coated with gold using an Ion JFC-1100 Sputter machine and examined using a JEOL T-300 SEM (JEOL, Tokyo, Japan). Between one and ten specimens of each parasite morphotype, including those 34 copepods morphologically examined, plus other 18 , were analysed using molecular techniques.

\section{Molecular analyses}

DNA sequences of several specimens of each parasite morphotype were analysed to determine whether the parasites belonged to different species. Genomic DNA was extracted from single specimens using the salting-out technique (extraction of DNA with salts). Given that there is almost no information on the family Pennellidae in the GenBank database, polymerase chain reaction (PCR) was performed targeting two genes: the D1-D2 regions of the large subunit of the 28S rRNA gene and the mitochondrial cytochrome $c$ oxidase subunit I (COI) gene, both of which have been used in phylogenetic studies on Caligidae (Oines and Heuch 2005, Oines and Schram 2008, Song et al. 2008, Morales-Serna et al. 2013). These genes were chosen to obtain an approximation at the family or genus (or even the species) level using the $28 \mathrm{~S}$ gene; the COI gene was used to perform specific identification (species level) or separation of species. The primers employed for PCR amplification were 28SF (5'-ACAACTGTGATGCCCTTAG-3') and 28SR (5'-TGGTCCGTGTTTCAAGACG-3') for the 28S rRNA gene (Song et al. 2008) and LCO (5'-GGTCAACAAATCATAAAGATATTGG-3') and HCO (5'-TAAACTTCAGGGTGACCAAAAAATCA-3') for the COI gene (Folmer et al. 1994).

Each PCR assay had a final volume of $25 \mu \mathrm{l}$ and included $0.125 \mu \mathrm{l}$ of Taq polymerase, $2.5 \mu \mathrm{l}$ of $10 \times$ PCR buffer, $0.5 \mu \mathrm{l}$ of dNTPs $(10 \mathrm{mM}), 4 \mu \mathrm{l}$ of $\mathrm{MgCl}_{2}(25 \mathrm{mM}), 1 \mu \mathrm{l}$ of primers (according to the gene analysed), $1.5 \mu \mathrm{l}$ of BSA (BioLabs) $(19 \mathrm{mg} / \mathrm{ml})$, $3 \mu \mathrm{l}$ of concentrated DNA (10 to $200 \mathrm{ng}$ of DNA) and $11.375 \mu \mathrm{l}$ 
Table 1. Prevalence of each morphotype (MT) of parasitic copepod found in assemblages of fish larvae from northern (off Coloso) and central Chile (off El Quisco). Family and species of fish and the average body length (BL) \pm standard deviation (SD) of the fish are also given.

\begin{tabular}{|c|c|c|c|c|c|c|c|c|c|}
\hline \multirow{2}{*}{ Localities } & \multirow{2}{*}{ Family and species of fish } & \multirow{2}{*}{$\begin{array}{c}\text { Fish } \\
\text { examined }\end{array}$} & \multirow{2}{*}{$\begin{array}{c}\mathrm{BL} \pm \mathrm{SD} \\
(\mathrm{mm})\end{array}$} & \multicolumn{6}{|c|}{ Copepod morphotypes } \\
\hline & & & & MT1 & MT2 & MT3 & MT4 & MT5, MT6 & MT7 \\
\hline \multirow[t]{9}{*}{ Coloso } & Gobiesocidae & & & & & & & & \\
\hline & Gobiesox marmoratus Jenyns & 217 & $2.9 \pm 1.7$ & 6.0 & 0.5 & 0 & 0 & 0 & 0.9 \\
\hline & Gobiidae & & & & & & & & \\
\hline & Ophiogobius jenynsi Hoese & 77 & $4.5 \pm 3.0$ & 10.4 & 2.6 & 0 & 0 & 0 & 0 \\
\hline & Labrisomidae & & & & & & & & \\
\hline & Auchenionchus crinitus (Jenyns) & 543 & $5.2 \pm 4.0$ & 2.4 & 1.5 & 0 & 0 & 0 & 0 \\
\hline & Tripterygiidae & & & & & & & & \\
\hline & Helcogrammoides chilensis (Cancino) & 56 & $4.0 \pm 0.4$ & 1.8 & 1.8 & 0 & 0 & 0 & 0 \\
\hline & Helcogrammoides cunninghami (Smitt) & 7 & $5.0 \pm 1.4$ & 14.3 & 28.6 & 0 & 0 & 0 & 0 \\
\hline \multirow[t]{13}{*}{ El Quisco } & Clinidae & & & & & & & & \\
\hline & Myxodes viridis Valenciennes & 117 & $7.1 \pm 1.1$ & 3.4 & 0 & 0 & 0 & 0 & 0.9 \\
\hline & Engraulidae & & & & & & & & \\
\hline & Engraulis ringens Jenyns & 31 & $13.8 \pm 3.7$ & 0 & 0 & 0 & 0 & 6.5 & 0 \\
\hline & Gobiesocidae & & & & & & & & \\
\hline & Gobiesox marmoratus & 785 & $6.8 \pm 1.5$ & 12.7 & 0.4 & 0.4 & 0.1 & 0.1 & 1.5 \\
\hline & Sicyases sanguineus Müller et Troschel & 425 & $7.4 \pm 0.8$ & 0 & 0.2 & 0 & 0 & 0.2 & 0 \\
\hline & Labrisomidae & & & & & & & & \\
\hline & Auchenionchus crinitus & 145 & $6.6 \pm 1.2$ & 0.7 & 0 & 0 & 0 & 0 & 0 \\
\hline & Auchenionchus microcirrhis (Valenciennes) & 50 & $8.7 \pm 2.5$ & 8.0 & 0 & 0 & 0 & 0 & 0 \\
\hline & Trypteriigidae & & & & & & & & \\
\hline & Helcogrammoides chilensis & 201 & $8.3 \pm 2.3$ & 4.0 & 0 & 0 & 0 & 0 & 0.5 \\
\hline & Helcogrammoides cunninghami & 667 & $8.9 \pm 3.8$ & 4.2 & 0.3 & 0.2 & 0.2 & 0 & 1.1 \\
\hline
\end{tabular}

Table 2. Number of larval fish species from northern (Antofagasta) and central (Valparaiso) Chile examined for endoparasites.

\begin{tabular}{|c|c|c|c|c|c|}
\hline \multirow{2}{*}{ Family and species of fish } & \multicolumn{2}{|c|}{ Antofagasta } & \multicolumn{2}{|c|}{ Valparaiso } & \multirow[b]{2}{*}{ Total } \\
\hline & Coloso & Mejillones & Montemar & El Quisco & \\
\hline \multicolumn{6}{|l|}{ Bathylagidae } \\
\hline Bathylagus ochotensis Schmidt & 1 & 1 & - & - & 2 \\
\hline \multicolumn{6}{|l|}{ Blenniidae } \\
\hline Hypsoblennius sordidus (Bennett) & 11 & 4 & - & - & 15 \\
\hline \multicolumn{6}{|l|}{ Clupeidae } \\
\hline Strangomera bentincki Norman & - & - & - & 67 & 67 \\
\hline Sardinops sagax (Jenyns) & 9 & - & - & - & 9 \\
\hline \multicolumn{6}{|l|}{ Dactyloscopidae } \\
\hline Sindoscopus australis Fowler et Bean & 13 & 3 & - & - & 16 \\
\hline \multicolumn{6}{|l|}{ Engraulidae } \\
\hline Engraulis ringens & 44 & 56 & - & - & 100 \\
\hline Gobiesocidae & - & - & - & - & - \\
\hline Gobiesox marmoratus Jenyns & 205 & 4 & 103 & 50 & 362 \\
\hline Sicyases sanguineus Müller et Troschel & 41 & 2 & - & - & 43 \\
\hline \multicolumn{6}{|l|}{ Gobiidae } \\
\hline Ophiogobius jenynsi Jenyns & 75 & - & - & - & 75 \\
\hline \multicolumn{6}{|l|}{ Kyphosidae } \\
\hline Species unidentified & - & 10 & - & - & 10 \\
\hline \multicolumn{6}{|l|}{ Labrisomidae } \\
\hline Auchenionchus crinitus (Jenyns) & 102 & 1 & 105 & - & 208 \\
\hline Auchenionchus sp. & 2 & 2 & - & - & 4 \\
\hline Calliclinus geniguttatus (Valenciennes) & 10 & 2 & - & - & 12 \\
\hline \multicolumn{6}{|l|}{ Myctophidae } \\
\hline Triphoturus oculeus (Garman) & 2 & - & - & - & 2 \\
\hline \multicolumn{6}{|l|}{ Normanichthyidae } \\
\hline Normanichthys crockeri Clark & 4 & 12 & - & - & 16 \\
\hline \multicolumn{6}{|l|}{ Pinguipididae } \\
\hline Pinguipes chilensis Valenciennes & 1 & 3 & - & - & 4 \\
\hline Prolatilus jugularis (Valenciennes) & 2 & 1 & - & - & 3 \\
\hline \multicolumn{6}{|l|}{ Sebastidae } \\
\hline Sebastes oculatus Valenciennes & 2 & - & - & - & 2 \\
\hline \multicolumn{6}{|l|}{ Tripterygiidae } \\
\hline Helcogrammoides chilensis (Cancino) & 48 & 9 & - & - & 57 \\
\hline Helcogrammoides cunnighami (Smitt) & 4 & - & 15 & 115 & 134 \\
\hline
\end{tabular}



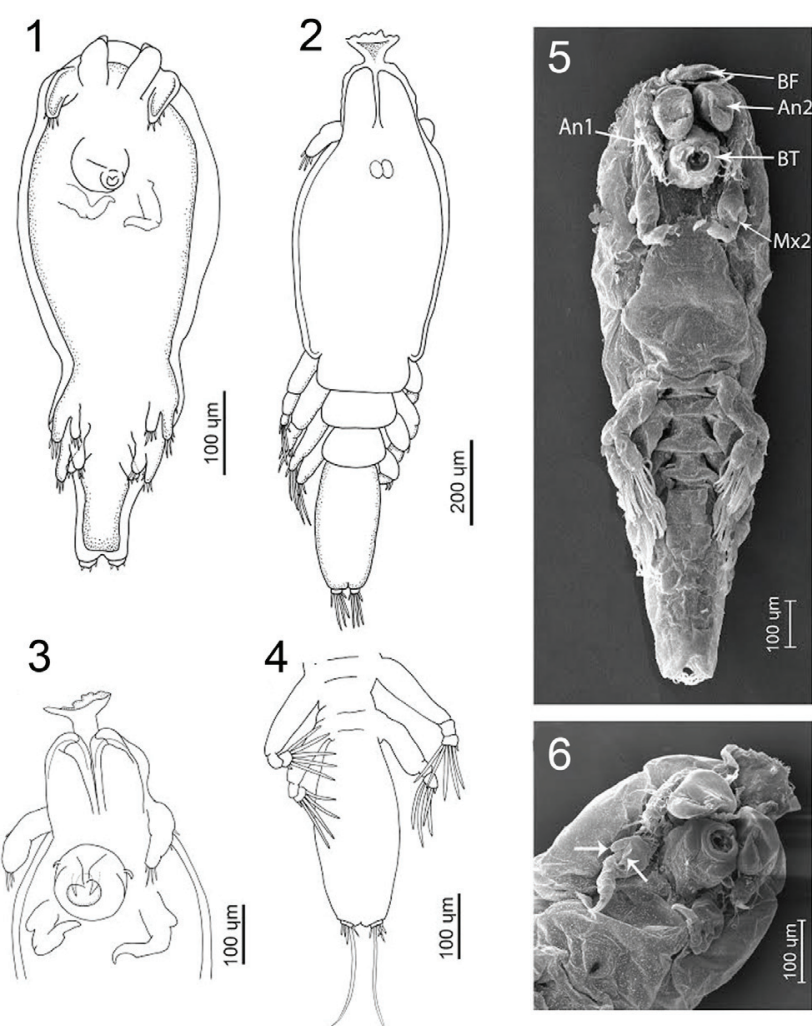

Figs. 1-6. Morphology of copepod Trifur sp. A - Morphotype 1 (Pennellidae). Fig. 1. Ventral body of an early chalimus. Fig. 2. Dorsal view of the body of a late chalimus. Fig. 3. Anteroventral region. Fig. 4. Third and fourth legs and genital complex. Fine hairs on the setae are not shown in drawings. Fig. 5. Scanning electron microscopy image of the ventral view. Fig. 6. Anteroventral portion of the body; arrows show the processes on the lacertus of the maxilla. Abbreviations: An1 - antennule; An2 - antenna; BF - base of the filament; BT - buccal tube; $\mathrm{Mx} 2$ - maxilla.

of water. The thermocycling conditions for the $28 \mathrm{~S}$ rRNA gene included an initial denaturation step at $94^{\circ} \mathrm{C}(5 \mathrm{~min})$, followed by 30 cycles at $94^{\circ} \mathrm{C}(30 \mathrm{~s}), 54^{\circ} \mathrm{C}(30 \mathrm{~s})$ and $72^{\circ} \mathrm{C}(1 \mathrm{~min})$, and a final extension step at $72^{\circ} \mathrm{C}(5 \mathrm{~min})$ (Song et al. 2008). For the COI gene, the following thermocycling profile was used for amplification: an initial denaturation step at $95^{\circ} \mathrm{C}(5 \mathrm{~min})$, followed by 40 cycles at $95^{\circ} \mathrm{C}(45 \mathrm{~s}), 50^{\circ} \mathrm{C}(45 \mathrm{~s})$ and $72^{\circ} \mathrm{C}(1 \mathrm{~min})$, and a final extension step at $72^{\circ} \mathrm{C}(10 \mathrm{~min})$ (Folmer et al. 1994).

PCR products were visualised on $1.5 \%$ agarose gels via electrophoresis and purified using the E.Z.N.A. kit (Omega Bio-Tek, Norcross, GA, USA). The products for each specimen were sequenced using an automated capillary electrophoresis sequencer (ABI 3730XL, Macrogen, Inc., Seoul, Korea). The sequences were edited using ProSeq v3.0 beta (Filatov 2002) and aligned with Clustal 2 (Larkin et al. 2007).

Sequences of the parasitic copepods of the family Bomolochidae von Nordmann, 1832 were used as the outgroup for comparison with the parasites analysed in this study; a sequence of the COI gene of Bomolochus cuneatus Fraser, 1920 was obtained from GenBank, whereas a sequence of the $28 \mathrm{~S}$ gene of an unidentified species of Bomolochidae from the fish Prolatilus jugularis (Valenciennes) collected off the coast of Chile was obtained during this study. Other adult parasite species of the genera Lepeophtheirus von Nordmann, 1832, Caligus Müller, 1785, Peniculus
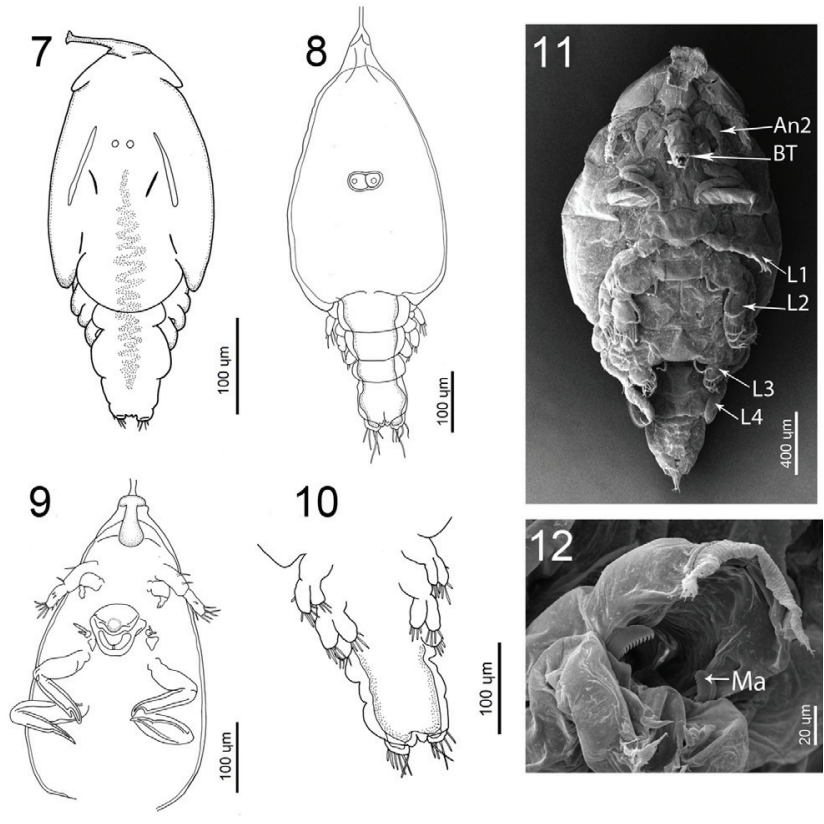

10
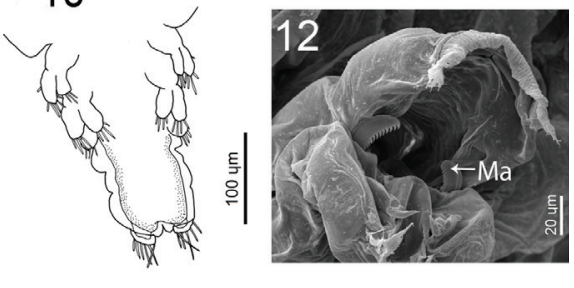

Figs. 7-12. Morphology of Caligus sp. A - Morphotype 2 (Caligidae). Fig. 7. Dorsal view of the body of a late chalimus. Fig. 8. Dorsal view of the body. Fig. 9. Anteroventral view of the cephalothorax; Fig. 10. Legs and genital complex of an early chalimus. Fine hairs on the setae are not shown in drawings.

Fig. 11. Scanning electron microscopy image of the ventral view of the whole body. Fig. 12. Buccal tube and mandible. Abbreviations: An2 - antenna; BT - buccal tube; L1 - first leg; L2 - second leg; L3 - third leg; L4 - fourth leg; Ma - mandible.

von Nordmann, 1832, Metapenniculus Castro et Baeza, 1985, Trifur Wilson, 1917 and Parabrachiella Wilson, 1915 were included in the analyses for comparison with the parasite morphotypes found in the fish larvae.

Phylogenetic trees were generated using MEGA v6 software (Tamura et al. 2013) with the Neighbour-Joining (NJ) algorithm (Nei and Kumar 2000) and the maximum composite likelihood (ML) evolution model (Tamura and Nei 1993). The NJ and ML methods employed a 1000 bootstrap replicate analysis to obtain nodal support. The NJ method utilised Kimura-2-parameters (K2P) as a model of evolution for both genes. ML utilised GTR $+\mathrm{G}+\mathrm{I}$ for the $28 \mathrm{~S}$ gene and GTR $+\mathrm{G}$ for the COI gene chosen according to Akaike information criterion values in Modeltest 3.7 (Posada and Crandall 1998). Finally, maximum parsimony analysis was performed using PAUP* 4.0b10 (Swofford 2001). Nodal support was estimated using 1000 bootstrap replicate analysis.

After confirming which parasite morphotypes could be distinguished as species, all of the parasites were examined again for reclassification to the lowest taxonomic level, according to the previously conducted morphological and molecular analyses. The abundance, intensity and prevalence of each parasite taxon were calculated at the two localities (Coloso and El Quisco).

\section{RESULTS}

A total sample of 5574 fish larvae of 40 species was collected in the nearshore region in the northern and central zones of Chile. Of these specimens, 1577 were from off Coloso and 3997 were from off El Quisco, corresponding to 20 and 37 fish species, respectively, at each locality. 

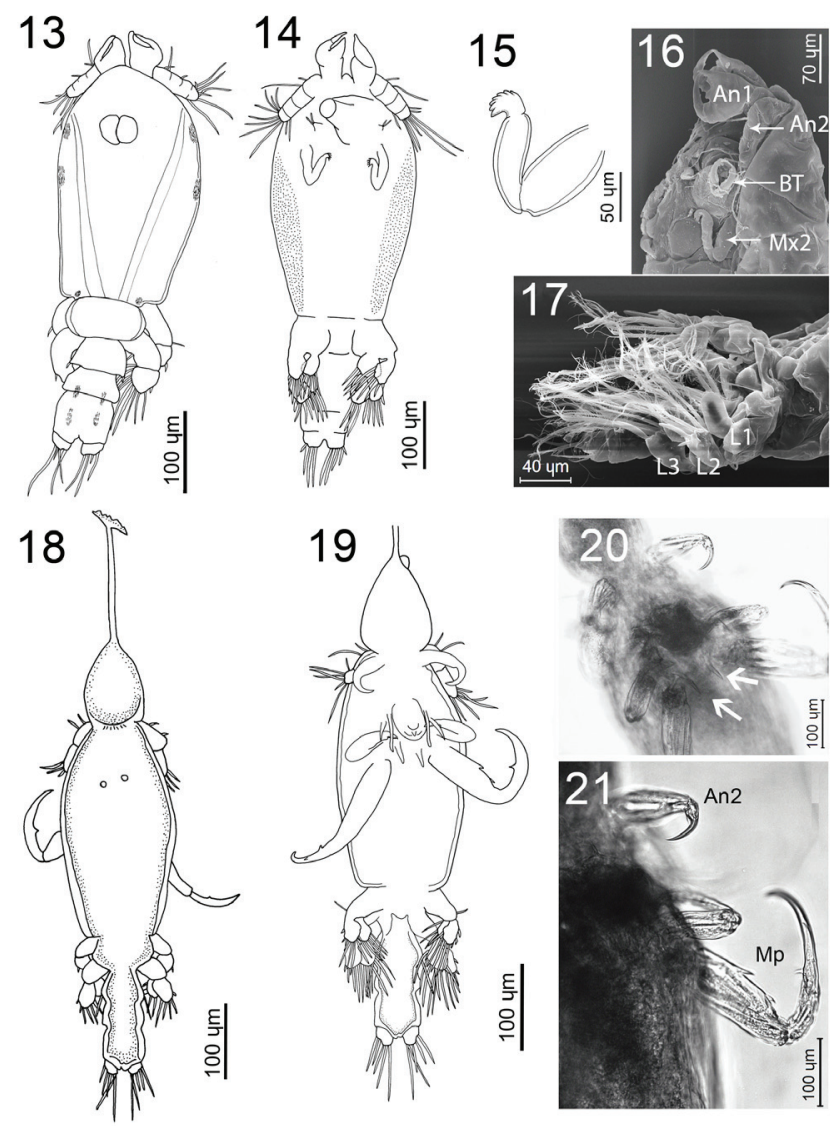

Figs. 13-21. Morphologies of undetermined parasitic copepods - Morphotype 3; Fig. 13. Dorsal view of the body. Fig. 14. Ventral view of the body. Fig. 15. Maxilla. Fig. 16. Scanning electron microscopy image of the anteroventral view. Fig. 17. Posteroventral view of the body. Figs. 18-21. Morphotype 4. Fig. 18. Dorsal view of the body. Fig. 19. Ventral view of the body. Fine hairs on the setae are not shown in drawings. Figs. 20-21. Photographs of the anteroventral part of the body (arrows in Fig. 22 show two ventral spines). Abbreviations: An1 - antennule; An2 - antenna; BT - buccal tube; Mp - maxilliped; Mx2 - maxilla; L1 - first leg; L2 - second leg; L3 - third leg.

We found that $3.6 \%$ of the fish from off Coloso and $4.4 \%$ of the fish from off El Quisco harboured ectoparasites in larval stages. Among all of the species collected at each locality, five fish species (25\%) from Coloso and eight species from El Quisco (19\%) hosted ectoparasites (Table 1). Furthermore, 686 of the fish larvae from off northern Chile and 455 from off central Chile were assessed for endoparasites. However, no endoparasites were found in these fish (Table 2).

\section{Parasite morphology}

Only parasitic copepods were found on fish larvae (Table 1). According to the available descriptions of the larval stages of other species of the Caligidae (e.g. Madinabeitia and Nagasawa 2011, Venmathi-Maran et al. 2013) or Pennellidae (e.g. Brooker et al. 2007, Ismail et al. 2013), the copepods collected in this study were designated as early and late development of chalimus stages. The main distinctions among the morphotypes are mentioned below.
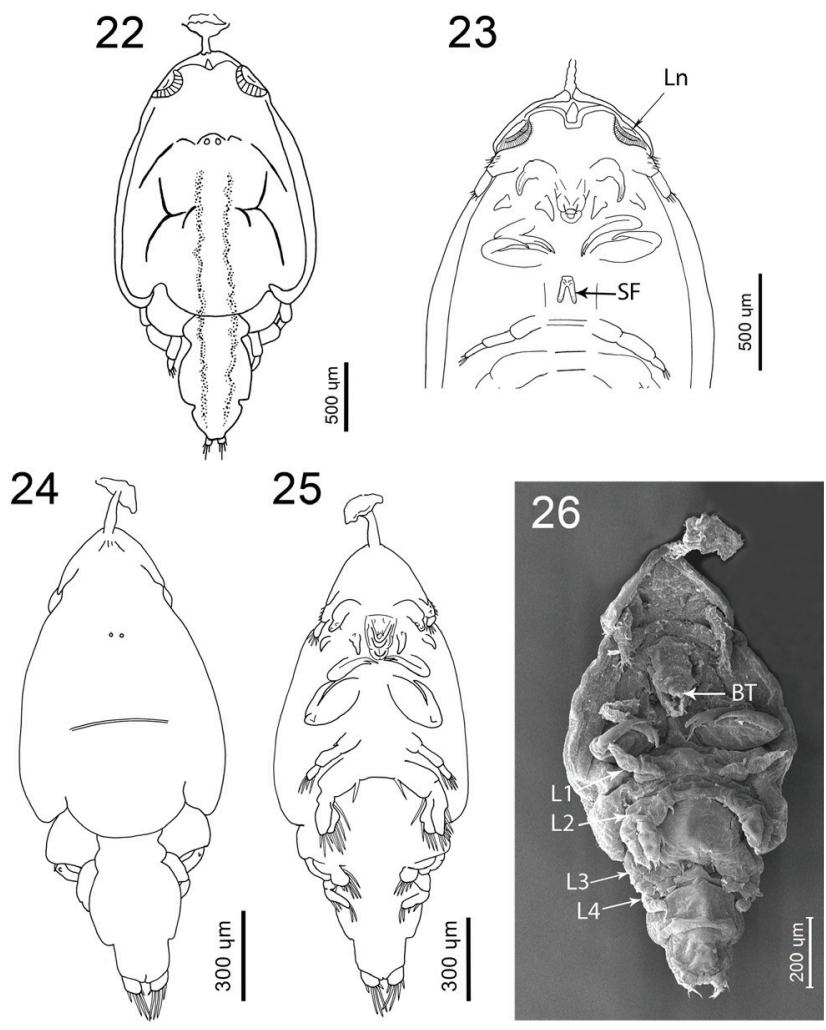

Figs. 22-26. Morphology of copepod Caligus sp. B. Fig. 22. Dorsal view of a developed chalimus - Morphotype 5 (Caligidae). Fig. 23. Ventral view of the cephalothorax - Morphotype 5 (Caligidae). Fig. 24. Dorsal view of the whole body of copepod - Morphotype 6 (Caligidae). Fig. 25. Ventral view of the whole body of copepod - Morphotype 6 (Caligidae). The fine hairs on the setae are not shown. Fig. 26. Scanning electron microscopy image of the ventral view of the whole body - Morphotype 6 (Caligidae). Abbreviations: BT - buccal tube; Ln - lunules; L1 - first leg; L2 - second leg; L3 - third leg; L4 - fourth leg; $\mathrm{SF}$ - sternal furca.

Morphotype 1 (Pennellidae) (Figs. 1-6): early and late chalimus. Total body length, 508-1 195. Antenna covered by membrane that belongs to filament base (Fig. 2). Cephalothorax longer than wide, 320-596 × 196-358. Buccal tube wide almost up to apical part (Figs. 2, 3, 6). No laminae at base of buccal tube (Fig. 6). Mandible inside buccal tube, with pointed, simple blade. Maxilla brachiform, lacertus with two strong processes in middle portion, with lateral process showing a rounded projection and ventral process with triangular projection (Figs. 3, 5, 6). Genital complex-abdomen almost oval in shape (Figs. 2, 4). Maxilliped absent (Figs. 1, 5, 6). First and second pairs of legs biramous (Fig. 4). Third and fourth pairs of legs poorly developed or absent in early development chalimus (Fig. 1). Third and fourth pairs of leg uniramous, present in late chalimus (Fig. 4).

Morphotype 2 (Caligidae) (Figs. 7-12): early and late chalimus. Total body length, 689-1 541, excluding setae on caudal ramus. Cephalothorax oval, longer than wide, 468-1007 × 272-710 (Figs. 7, 8, 9). Buccal tube some distance from anterior extremity of body, its length representing $15-16 \%$ of body length (Figs. 9,11 ). Mandible in- 

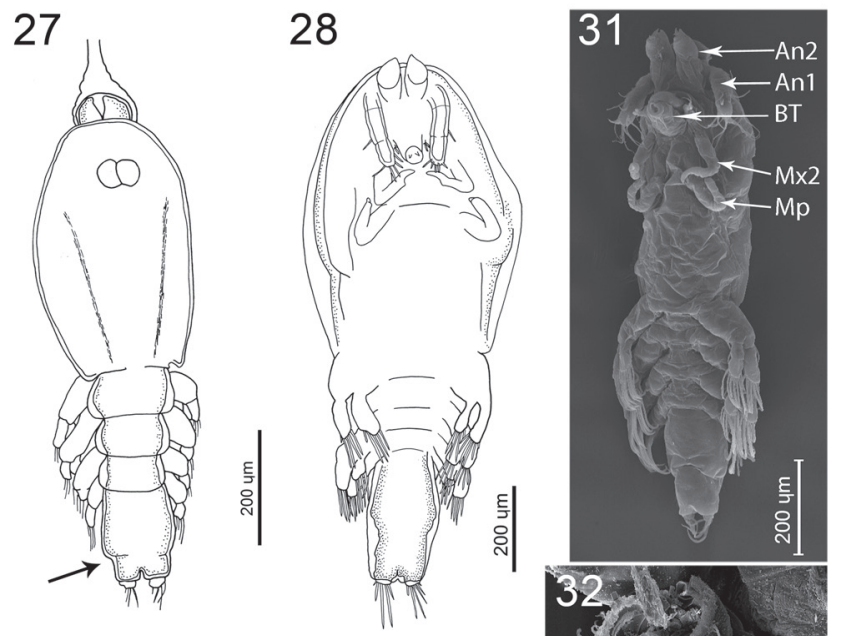

29

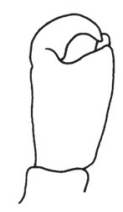

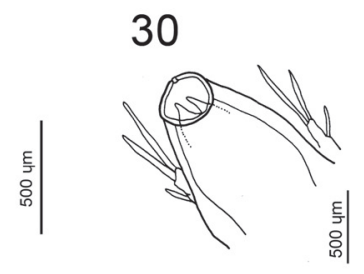

ह

Figs. 27-32. Morphology of copepod Trifur sp. 2-Morphotype 7 (Pennellidae). Fig. 27. Dorsal view of the body (arrow shows the constriction in the abdomen); Fig. 28. Ventral view of the body of an advanced chalimus. Fig. 29. Antenna; Fig. 30. Buccal tube and maxillule. Fine hairs on the setae are not shown. Fig. 31. SEM image of the ventral view of the body; Fig. 32. Laminae at the buccal tube. Arrows in Fig. 34 show the processes on the lacertus in the maxilla. Abbreviations: An1 - antennule; An2 - antenna; BT - buccal tube; La - lacertus; Lm - laminae; Mx2 - maxilla; Mx1 - maxillule; Mp - maxilliped.

side buccal tube, with pointed and serrated blade (Fig. 12). Sternal furca and lunules not observed (Figs. 7-9, 11). First and fourth legs uniramous. Second and third legs biramous (Figs. 10, 11).

Morphotype 3 (Figs. 13-17): copepodid. Total body length, 486-1 004, cephalothorax oval, 300-599 long excluding setae on caudal ramus, 176-374 wide. Antenna and antennule segmented (Figs. 13, 14, 16). Antenna wide with slender claw (Fig. 16). Maxillule with two setae (Fig. 16). Buccal tube wide at base, narrower in apical portion (Fig. 14). Maxilla two-segmented, lacertus and brachium with smooth surface, terminally with claw with 7 teeth (Figs. 15, 16). Maxilliped not observed. Two or three pairs of biramous legs (Figs. 14, 17).

Morphotype 4 (Figs. 18-21): late chalimus. Body length 507-547, excluding setae on caudal ramus. Cephalothorax oval, 315-339 long, 177-194 wide. Frontal filament long, with large bulbous base (Fig. 18). Around buccal tube, 2 pairs of large, simple, rigid structures; another pair similar but shorter, posterior to buccal tube (Figs. 19, 20). Maxilla two-segmented, lacertus and brachium with smooth surface, terminally with serrated claw. Maxilliped large, two-segmented, bearing two spine-like structures on corpus and spine in middle part of subchela (Figs. 19, 21).
Second and third legs biramous (Figs. 18, 19). Third leg composed of one long seta and 1 short seta (Figs. 18, 19).

Morphotype 5 (Caligidae) (Figs. 22, 23): late chalimus. Frontal filament present. Total body length 2812-3043, excluding setae on caudal ramus. Cephalothorax oval, 1906-1 956 long × 1370-1 468 wide (Fig. 22). Post-antennary process pointed, appearing as claw (Fig. 23). Buccal tube a short distance from anterior extremity of body, its length representing $16 \%$ of body length (Fig. 23). Sternal furca present (Fig. 23). First and fourth legs uniramous; second and third legs biramous.

Morphotype 6 (Caligidae) (Figs. 24-26): late chalimus. Total body length 1 192-1 555 excluding setae on caudal ramus. Cephalothorax oval, 754-1 140 long $\times$ 528-666 wide (Figs. 24-26). Proportion of distance from anterior edge of buccal tube to anterior edge of body divided by total body length $0.21-0.22$ (Figs. 25, 26). Post-antennary process pointed, no setules or setae observed. Buccal tube wider at base and narrower in apical portion. Maxillule as an inverted triangle with two setae anteriorly (Fig. 25). Maxilla two-segmented, lacertus and brachium with smooth surface, terminally with two unequal elements. Maxilliped large but unarmed, subchela sharply pointed (Figs. 25, 26). Sternal furca not observed. First and fourth legs uniramous (Figs. 25, 26). Second and third legs biramous (Figs. 25, 26). Fifth legs rudimentary.

Morphotype 7 (Pennellidae) (Figs. 27-32): late chalimus. Total body length 696-1 141. Cephalothorax longer than wide, 418-562 × 266-376, with rounded projections at posterolateral corners (Fig. 27). Genital complex almost oval in shape, with constriction in middle zone (Figs. 27, 28, 31). Buccal tube wide at base, narrower in apical portion (Figs. 30, 32). Two lines of small laminae at base of buccal tube (Fig. 32). Mandible inside buccal tube, with pointed, simple blades. Maxilla brachiform, lacertus with two processes in middle part, both with triangular projections (Fig. 32); brachium slender, with claw extended from terminal part. Maxilliped present; twosegmented, terminal portion almost rounded, with small claw (Figs. 28). First and second pairs of legs biramous (Figs. 28, 31). Third and fourth pairs of leg uniramous.

\section{Molecular analyses}

Samples of all of the collected copepod morphotypes were subjected to DNA extraction. However, DNA extraction and PCR sequencing were successful for only five morphotypes (MT1, MT2, MT5, MT6 and MT7). Analysis of the molecular sequences obtained for the 28S rRNA gene revealed that the two types of Pennellidae collected (MT1 and MT7) belong to the genus Trifur (Fig. 33) with a genetic distance of $0 \%$ (Table 3 ). A specimen of Pennellidae (designated as Afta2 MT7), included in the 28S rRNA gene analysis only, was different from the other pennellids (MT1, MT7) (Fig. 33; Table 3). In contrast, COI sequence analysis indicated that Pennellidae MT1 and MT7 were different species (Fig. 34). Additionally, MT1 exhibited a genetic difference of only $0.9 \%$ with adult Trifur from Merluccius gayi (Guichenot), indicating that these copepods likely belong to the same species (Table 4). 


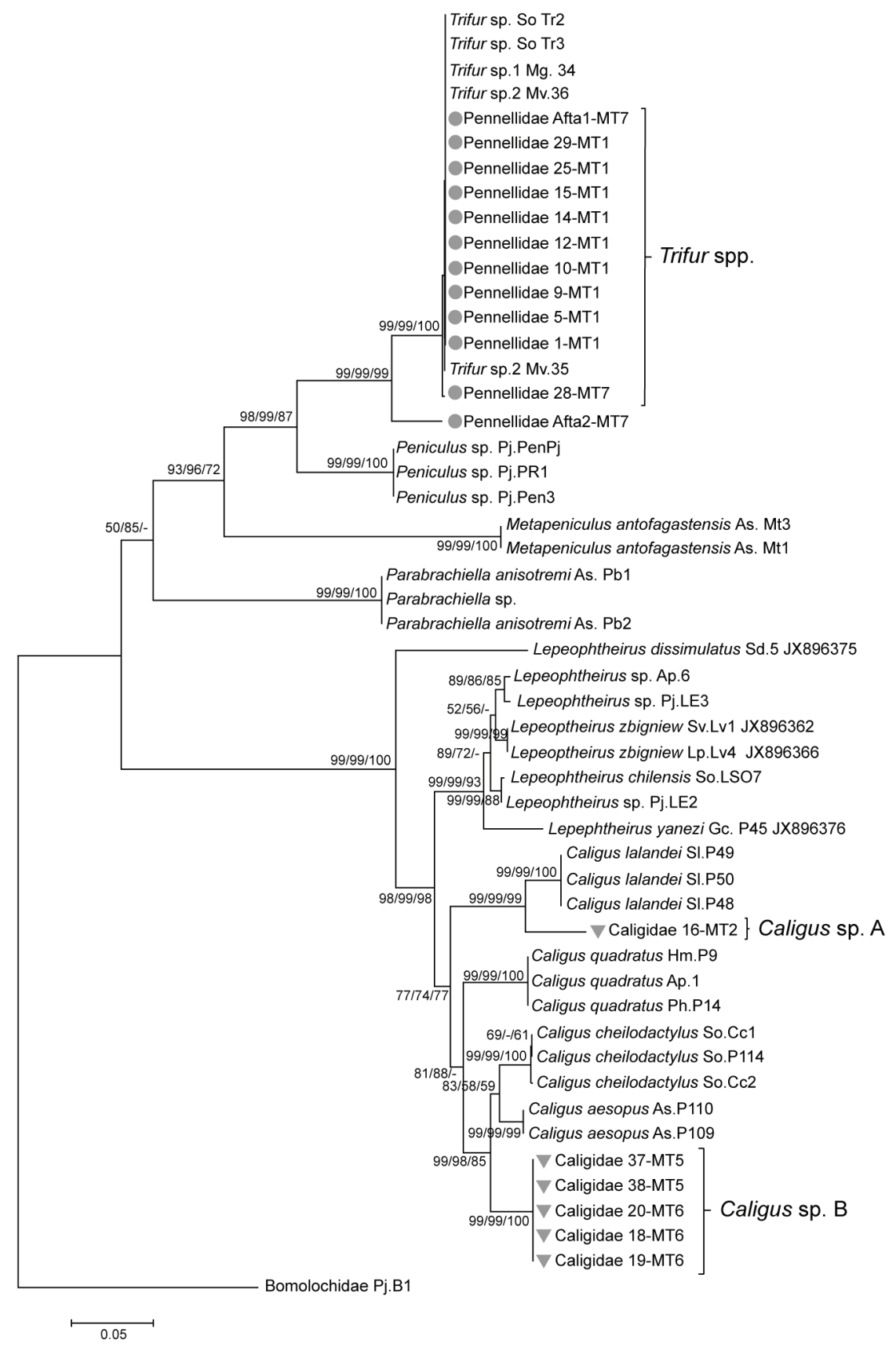

Fig. 33. Phylogenetic tree showing the relationships among the ectoparasite larvae identified in this study, including species of Caligidae, Pennellidae and Bomolochidae. The phylogenetic tree is based on Neighbour-Joining (NJ) analyses of 28S rRNA gene sequences. The numbers along the branches indicate the percentages of supporting values resulting from the different analyses, in the following order: NJ, maximum composite likelihood and maximum parsimony. Values lower than $50 \%$ are indicated with dashes. Symbols indicate the specimens of Pennellidae (circles) and Caligidae (inverted triangles) collected in this study. Abbreviations: Ap - Acanthistius pictus (Tschudi); As - Anisotremus scapularis (Tschudi); Gc - Genypterus chilensis (Guichenot); Hm - Hemilutjanus macrophthalmos (Tschudi); Lp - Labrisomus philippii (Steindachner); Mg - Merluccius gayi (Guichenot); MT - morphotype; Mv - Myxodes viridis (Valenciennes); $\mathrm{Ph}$ - Paralabrax humeralis (Valenciennes); $\mathrm{Pj}$ - Prolatilus jugularis (Valenciennes); Sd - Semicossyphus darwini (Jenyns); S1 - Seriola lalandi (Cuvier et Valenciennes); So - Sebastes oculatus (Valenciennes); Sv - Scartichthys viridis (Valenciennes).

Regarding the family Caligidae, analysis of the $28 \mathrm{~S}$ rRNA gene sequences showed that the three morphotypes classified within Caligidae (MT2, MT5 and MT6) belong to the genus Caligus (Fig. 33). This result was in part corroborated by the COI gene analysis (Fig. 34), which also indicated that the three morphotypes of Caligidae corresponded to only two species. Caligidae MT6 and MT5 showed little genetic difference $(0.7 \%$ and $4 \mathrm{bp}$, Table 4$)$, indicating that they are the same species, but at different chalimus stages because of their different morphology.

\section{Parasite burdens}

Pennellid copepods (MT1 and MT7) were the most common parasites at both localities (Coloso and El Quisco), revealing prevalences between 0.5 and $14 \%$ (Table 1). Multispecific infections in an individual host (up to two ec- 
Table 3. Pairwise sequence divergences for the $28 \mathrm{~S}$ region of the rDNA gene among parasitic copepods found in marine fish from Chile, sequenced in this study. The divergence distances were calculated using the maximum composite likelihood model and are shown as a percentage (below the diagonal). The mean number of mutations between pairwise comparisons is also shown for each clade (above the diagonal).

\begin{tabular}{|c|c|c|c|c|c|c|c|c|c|c|c|c|}
\hline & Parasitic copepods & 1 & 2 & 3 & 4 & 5 & 6 & 7 & 8 & 9 & 10 & 11 \\
\hline 1 & Pennellidae MT1 & - & 1 & 0 & 0 & 0 & 0 & 39 & 218 & 218 & 226 & 218 \\
\hline 2 & Pennellidae MT7 & 0.2 & - & 1 & 1 & 1 & 1 & 40 & 218 & 218 & 226 & 218 \\
\hline 3 & Pennellidae Afta1 MT7 & 0 & 0.2 & - & 0 & 0 & 0 & 39 & 218 & 218 & 226 & 218 \\
\hline 4 & Trifur sp. So & 0 & 0.2 & 0 & - & 0 & 0 & 39 & 218 & 218 & 226 & 218 \\
\hline 5 & Trifur sp. $1 \mathrm{Mg}$ & 0 & 0.2 & 0 & 0 & - & 0 & 39 & 218 & 218 & 226 & 218 \\
\hline 6 & Trifur sp. $2 \mathrm{Mv}$ & 0 & 0.2 & 0 & 0 & 0 & - & 39 & 218 & 218 & 226 & 218 \\
\hline 7 & Pennellidae Afta2 MT7 & 6.2 & 6.4 & 6.2 & 6.2 & 6.2 & 6.2 & - & 216 & 216 & 222 & 215 \\
\hline 8 & Caligidae MT6 & 45.4 & 45.3 & 45.4 & 45.4 & 45.4 & 45.4 & 44.8 & - & 0 & 84 & 71 \\
\hline 9 & Caligidae MT5 & 45.4 & 45.3 & 45.4 & 45.4 & 45.4 & 45.4 & 44.8 & 0 & - & 84 & 71 \\
\hline & Caligidae MT2 & 47.9 & 47.8 & 47.9 & 47.9 & 47.9 & 47.8 & 46.6 & 13.8 & 13.8 & - & 38 \\
\hline & Caligus lalandei & 45.7 & 45.6 & 45.7 & 45.7 & 45.7 & 45.7 & 44.8 & 11.6 & 11.6 & 5.9 & - \\
\hline
\end{tabular}

Abbreviations: Mg - Merluccius gayi (Guichenot); MT - morphotype; Mv - Myxodes viridis (Valenciennes); So - Sebastes oculatus (Valenciennes).

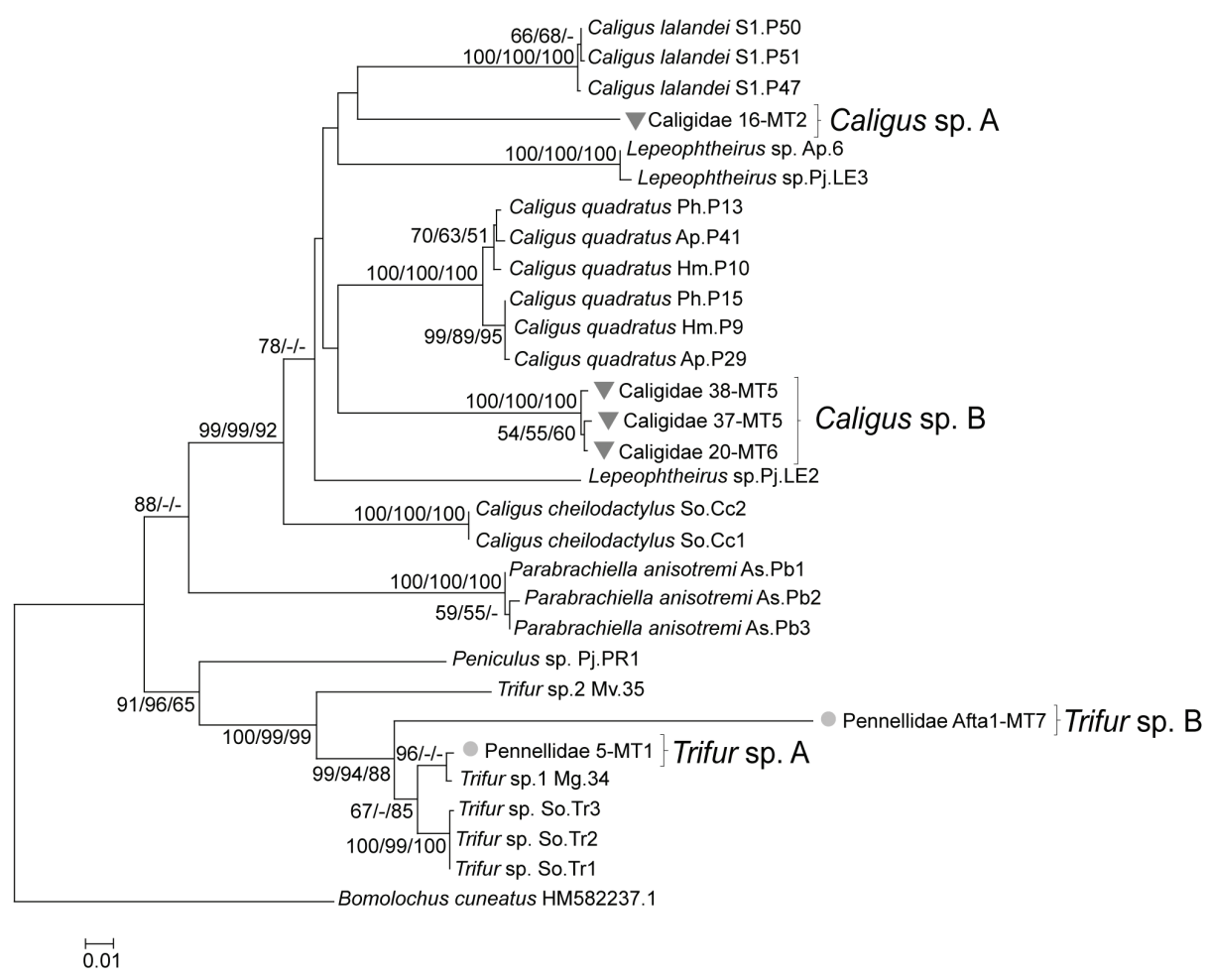

Fig. 34. Phylogenetic tree showing the relationships among the ectoparasite larvae identified in this study, including species of Caligidae and Pennellidae. The phylogenetic tree is based on Neighbour-Joining (NJ) analyses of the COI gene. The numbers along the branches indicate the percentages of supporting values resulting from the different analyses, in the following order: NJ, maximum composite likelihood and maximum parsimony. Values lower than 50\% are indicated with dashes. Symbols indicate the specimens of Pennellidae (circles) and Caligidae (inverted triangles) collected in this study. Abbreviations: Ap - Acanthistius pictus (Tschudi); As - Anisotremus scapularis (Tschudi); Hm - Hemilutjanus macrophthalmos (Tschudi); Mg-Merluccius gayi (Guichenot); MT - morphotype; $\mathrm{Mv}$ - Myxodes viridis (Valenciennes); $\mathrm{Ph}$ - Paralabrax humeralis (Valenciennes); $\mathrm{Pj}$ - Prolatilus jugularis (Valenciennes); $\mathrm{Sl}$ - Seriola lalandi (Cuvier et Valenciennes); So - Sebastes oculatus (Valenciennes).

toparasite species) were infrequent $(0.05 \%$ in El Quisco). The prevalences of copepod species and their sample sizes were variable among the fish (Table 1). Despite the small sample size of Helcogrammoides cunninghami (Smitt) $(\mathrm{n}=7)$, it displayed the highest prevalence of infection with Trifur sp. A (14\%, Pennellidae MT1) and Caligus sp. A (29\%, Caligidae MT2) (Table 1), followed by Ophiogobius jenynsi Hoese (10\%) in fish samples from northern Chile (Coloso), whereas Gobiesox marmoratus displayed the highest prevalence of Trifur sp. A (13\%, Pennellidae MT1) among fishes from central Chile (off El Quisco). The prevalence of copepod species in other larval fish species ranged between $<1-6 \%$. Similarly, the parasite intensity was low. Pennellidae MT1 and MT7 (Trifur sp. A and B, respectively) and Caligidae MT2 (Caligus sp. A) ranged between 1-2 parasites/host; copepods MT3 and MT4 had one parasite/host, and Caligidae MT6 (Caligus sp. B) had two parasites/host. The clingfish G. marmoratus exhibited 
Table 4. Pairwise sequence divergences for the mitochondrial COI gene among parasitic copepods found in marine fish from Chile, sequenced in this study. The divergence distances were calculated using the maximum composite likelihood model and are shown as a percentage (below the diagonal). The mean number of mutations between pairwise comparisons is also shown for each clade (above the diagonal).

\begin{tabular}{|c|c|c|c|c|c|c|c|c|c|c|}
\hline & Parasitic copepods & 1 & 2 & 3 & 4 & 5 & 6 & 7 & 8 & 9 \\
\hline 1 & Pennellidae MT1 & - & 99 & 18.3 & 5 & 61 & 144 & 147 & 155 & 145 \\
\hline 2 & Pennellidae MT7 & 20.3 & - & 106.3 & 99 & 137 & 186 & 189 & 209 & 192.7 \\
\hline 3 & Trifur sp. So & 3.3 & 22.1 & - & 15.3 & 72.3 & 144.3 & 145.8 & 155.7 & 138.3 \\
\hline 4 & Trifur sp. $1 \mathrm{Mg}$ & 0.9 & 20.3 & 2.8 & - & 65 & 145 & 148 & 155 & 143 \\
\hline 5 & Trifur sp. $2 \mathrm{Mv}$ & 11.9 & 30.1 & 14.4 & 12.8 & - & 134 & 134 & 156 & 144.3 \\
\hline 6 & Caligidae MT6 & 31.3 & 44.3 & 31.4 & 31.6 & 28.7 & - & 4 & 119 & 114.7 \\
\hline 7 & Caligidae MT5 & 32 & 45.2 & 31.8 & 32.3 & 28.6 & 0.7 & - & 120 & 116.7 \\
\hline 8 & Caligidae MT2 & 34.3 & 52.3 & 34.5 & 34.3 & 34.6 & 25.1 & 25.4 & - & 105 \\
\hline 9 & Caligus lalandei & 31.6 & 46.5 & 29.8 & 31 & 31.4 & 24 & 24.5 & 21.6 & - \\
\hline
\end{tabular}

Abbreviations: $\mathrm{Mg}$-Merluccius gayi (Guichenot); MT - morphotype; Mv - Myxodes viridis (Valenciennes); So - Sebastes oculatus (Valenciennes).

the richest array of parasites; this fish species exhibited all of the identified copepod morphotypes (Table 1).

\section{DISCUSSION}

\section{Species richness of parasites on fish larvae}

Fish larvae of nine of the 40 fish species examined in this study were parasitised by copepods. Although the prevalences of parasites were mostly low (Table 1), the total richness of ectoparasites reached six copepod species, which could be considered to be high in fish larvae that are both small and very young (from a couple of days to two months old). However, the taxonomic diversity of parasites on fish larvae was low because only copepods were found. Thus, the parasite community of fish larvae in the nearshore waters of northern and central Chile was composed only of copepods: two Trifur spp., two Caligus spp. and two other species that remained undetermined.

We distinguished two pennellid species (MT1 and MT7) based on their morphologies, mainly in relation to the shape of the buccal tube and abdomen shape, and the presence of maxilipeds. Pennellid MT1 was characterised by a wider buccal tube, a subcylindrical abdomen, and the lack of maxillipeds (Figs. 1-6). In contrast, pennellid MT7 possessed an almost conical buccal tube, narrow posterior part of the abdomen and maxillipeds were present (Figs. 27-32). These species differed from each other molecularly using the COI gene, although both belonged to the genus Trifur. Due to lower variability of the 28S rRNA gene, the analyses based on this gene resulted in that most of the pennellid species sequenced in this study (from larval and adult fish) appeared in one clade representing the genus Trifur (Fig. 33). However, one species (similar to the morphotype MT7) was genetically different from the other morphotypes in the $28 \mathrm{~S}$ rRNA gene, suggesting that there is another species of Trifur on fish larvae.

Twelve species of the Pennellidae (including some species erroneously placed in the freshwater family Lernaeidae Cobbold, 1879; see Muñoz and Olmos 2007) have been recorded in marine fish from off the Chilean coast; two of these species belong to the genus Trifur: T. puntaniger Thomé, 1963 and T. tortuosos Wilson, 1917. The latter species has been recorded in several benthic and demersal fishes. However, there are also a few records of an unidentified species of Trifur found in intertidal fish species (Muñoz and Olmos 2007). Therefore, our ability to identify pennellids at the larval stage is limited, even when molecular techniques are used. The DNA sequence analyses revealed that the specimens of Trifur collected from $\mathrm{Se}$ bastes oculatus (Valenciennes) and Myxodes viridis (Valenciennes) are actually different species (Fig. 33). Pennellidae MT1 (Pennellidae 5 MT1; Fig. 33) was the only species closer to the specimens collected from Merluccius gayi, which had been identified as T. tortuosus in previous studies (Atria 1977, George-Nascimento 1996). However, due to poor understanding of the taxonomy of the Pennellidae in Chile, the previous identifications of these copepods may appear to be erroneous.

Two morphotypes of Caligidae (MT2, MT5-MT6) were recognised in the larval fish sample, but molecular data (Figs. 33, 34) demonstrate that morphotypes 5 and 6 belong to the same species. Both species belong to the genus Caligus and are differentiated according to their morphology and sequences of the 28S rRNA and COI genes. Caligidae MT5 was an advanced stage of MT6, as evidenced by its greater body size and the presence of lunules and sternal furca. Caligids MT2 and MT6 differed from one another in the distance from the anterior edge to the buccal tube and chalimus III or IV, which was greater in MT 6 (Figs. 9, $11,25,26)$, and the third leg, where the lobule bearing the exo- and endopods was wider in MT6 (Figs. 25, 26) than in MT2 (Figs. 7, 8). The sequences obtained from these two copepods did not match any of the four Caligus spp. that have been reported from littoral fish in Chile (C. lalandaei Barnard, 1948, C. quadratus Shiino, 1954, C. cheilodactylus Kröyer, 1863 and C. aesopus Wilson, 1921; Figs. 33, 34). These four species are the most common along the northern and central Chilean coast of a total of 12 species of Caligus known in Chile. Therefore, we cannot conclude whether the species of Caligus found on fish larvae have already been described.

Copepods MT3 and MT4 could not be identified as belonging to any family or genus group. Unfortunately, molecular analyses could not be applied to these specimens because DNA extractions were not successful. Morphological comparisons of larval copepods are difficult for most 
species because the larval stages are usually unknown and adults can be morphologically very different from the larvae (e.g. González and Carvajal 2003, Brooker et al. 2007). Nevertheless, there are some features indicating that these copepod morphotypes do not belong to Caligidae and Pennellidae. Copepod MT3 exhibits a particular shape of the maxilla, a short and serrated claw (Figs. 15, 16). In contrast, copepod MT4 shows six rigid structures in the ventral zone around the buccal tube, which, to our knowledge, has not been described previously in any species. The maxilliped of this species is large, with a strong corpus and a large subchela. Both copepod morphotypes (MT3 and MT4) have buccal tubes, suggesting that they belong to the order Siphonostomatoida.

Endoparasites were not present in the fish species examined. The biology of endoparasites is different from that of ectoparasites; endoparasites exhibit a complex life cycle involving 1-3 intermediate hosts. Once these parasites enter their intermediate hosts, they cannot detach, and transmission to the next host occurs via a passive route, through predation. Fish larvae feed on planktonic organisms such as the calanoid copepods, nauplii, copepodids and eggs of various crustaceans, ostracods, and the larvae of bivalves and polychaetes (Balbontín et al. 1997, Ochoa-Muñoz et al. 2013). All of these organisms exhibit small sizes and short life-spans, which reduces their likelihood of becoming parasitised (González 1998). In fact, planktonic invertebrates usually show low parasitic prevalences (Rusinek et al. 1996, Morais-Falavigna et al. 2003, Riscala-Madi et al. 2011).

\section{Role of fish larvae in parasite life cycles}

According to the findings of this study, fish larvae from the Chilean nearshore region do not play an important role in the life cycles of endoparasites. Fish larvae may serve as intermediate hosts for some ectoparasites that have complex life cycles, with more than one host species. Most ectoparasites display a direct life cycle, which implies the existence of different larval stages on a single host (the definitive host; Boxshall 2005). Several parasitic crustaceans, however, use intermediate hosts for completing their larval development, while their definitive hosts belong to other species with larger body sizes (Anderson and Dale 1981) or hosts from different habitats (Brooker et al. 2007).

Pennellid copepods require one (Anstensrud and Schram 1988, Ismail et al. 2013) or two hosts (Brooker et al. 2007) over the course of their life, which may depend on the parasite species involved. Therefore, species of Trifur (Pennellidae MT1 and MT7) may use fish larvae as intermediate hosts only. First, different chalimus stages were found on the fish larvae, meaning that they can develop during the parasitic larval stages. Second, the small body size of the fish (Table 1) makes it unlikely that parasites will reach maturity in these fish, because fish larvae have shown growth rates between 0.14 and $0.24 \mathrm{~mm} /$ day (Contreras et al. 2013, Plaza et al. 2013), which implies that it takes several months for fish to reach an adequate body size to energetically support large parasites. GeorgeNascimento et al. (2004) indicated that small hosts would not be able to support the energetic demands of large or abundant parasites. Third, species of Trifur have been recorded on fish from different habitats, such as the Scorpaenidae, Merlucciidae from dermesal habitats and the Labrisomidae and Gobiesocidae from the intertidal zone. However, it seems that infection with Trifur occurs in the water column in the nearshore zone, where fishes of the families Scorpaenidae and Merlucciidae normally live (Muñoz and Olmos 2007), as opposed to the intertidal zone where Trifur larvae have never been found on adult intertidal fish and adults are found only rarely (Muñoz and Castro 2012, Muñoz 2014). In our study, Trifur sp. A (MT1) from fish larvae had a genetic match with an adult Trifur sp. 1 from Merluccius gayi (Merlucciidae), indicating that the life cycle of this Trifur sp. can be completed on fish from demersal habitats.

The caligid species found on larval fish may use them as intermediate hosts. Species of Caligus found in the present study were at different chalimus stages, which indicates that they can develop in larval stages on these little fish that were mainly intertidal species as adults (i.e. species of the Gobioesocidae, Clinidae, Labrisomidae and Tripterygiidae; Table 1). However, species of Caligus are not common on fish from intertidal rocky pools (e.g. PardoGandarillas et al. 2004, Flores and George-Nascimento 2009, Muñoz and Delorme 2011), except the juveniles of Bovichthys chilensis Regan, which were parasitised by $\mathrm{Ca}$ ligus sp. with a prevalence of $2.8 \%$ in the central-southern region of Chile (Muñoz et al. 2002). Therefore, we suggest that intertidal fish are not common definitive hosts for $\mathrm{Ca}$ ligus spp. and that nearshore larval fish are being used as intermediate hosts by these copepods.

In this study, we determined that parasitic copepod larvae, both pennellids and caligids, have exploited larval hosts to reach a sufficient stage of development to enable them to detach from their host and swim, searching for their definitive hosts. This process can be considered a strategy that also allows the parasitic copepods to infect hosts of different sizes and to achieve major spatial dispersion through mobile young hosts. However, parasitic copepods remained in nearshore habitats parasitising definitive hosts, such as demersal and subtidal fish (e.g. Muñoz et al. 2002, Henriquez and González 2014), because intertidal fish larvae are not common definitive hosts for these groups of parasites, even though some species live between the intertidal and subtidal zone.

This study also revealed that there are some issues in the taxonomy of copepods from Chile. We could not identify all of the copepod species found on the fish larvae because there are few pennellids identified on fish from Chile and these copepods are not frequent in adult fish (e.g. GeorgeNascimento 1996, Muñoz and Castro 2012, Muñoz 2014). Caligids are better studied, but we could not identify the species that we found, even when molecular analyses were used. Identifications of copepods MT3 and MT4 were not possible and still we do not have any knowledge to further their taxonomical identifications. Therefore, there is still a lot of work to do related to parasitic larval stages of copepods, not only in their descriptions and identification but 
also in their biology and the host species they need during their lives.
Acknowledgements. We thank Mario George-Nascimento for facilitating the collection of some specimens of Trifur used in molecular analyses. This study was supported by the FONDECYT (Regular grant No. 1120868 to GM, ML and MTG).

\section{REFERENCES}

Anderson G., Dale W. 1981: Probopyrus pandalicola (Packard) (Isopoda: Epicaridae): morphology and development of larvae in culture. Crustaceana 41: 143-161.

Anstensrud M., Schram T.A. 1988: Host and site selection by larval stages and adults of the parasitic copepod Lernaeenicus sprattae (Sowerby) (Copepoda, Pennellidae) in the Oslofjord. Hydrobiologia 47: 587-595.

Atria G. 1977: Lista de copépodos asociados a organismos marinos en Chile (Caligoidea, Lerneapoidea, Cyclopoida). Not. Mens. Mus. Nac. Hist. Nat. 21: 2-7.

Balbontín F., Llanos A., Valenzuela V. 1997: Sobreposición trófica e incidencia alimentaria en larvas de peces de Chile central. Rev. Chil. Hist. Nat. 70: 381-390.

Balbontín F., Pérez R. 1979: Modalidad de postura, huevos y estados larvales de Hypsoblennius sordidus (Bennett) en la Bahía de Valparaíso (Blenniidae: Perciformes). Rev. Biol. Mar. 16: 311-318.

Balbuena J.A., Karlsbakk E., Kvensenth A.M., Saksvik M., NyLund A. 2000: Growth and emigration of the third-stage larvae of Hysterotylacium aduncum (Nematoda: Anisakidae) in larval herring Clupea harengus. J. Parasitol. 86: 1271-1275.

Bourque J.-F., Dibson J.J., Ryan D.A.J., Marcogliese D.J. 2006: Cestode parasitism as a regulator of early life-history survival in an estuary population of rainbow smelt Osmerus mordax. Mar. Ecol. Prog. Ser. 314: 295-307.

Boxshall G. 2005: Copepoda (copepods). In: K. Rohde (Ed.), Marine Biology. CSIRO Publishing, Collingwood, pp. 123-138.

Brooker A.J., Shinn A.P., Bron J.E. 2007: A review of the biology of the parasitic copepod Lernaeocera branchialis (L., 1767) (Copepoda: Pennellidae). Adv. Parasitol. 65: 297-341.

Castro R., Baeza H. 1986: Premetamorphosis stages of two pennellids (Copepoda, Siphonostomatoida) from their definitive hosts. Crustaceana 50: 166-175.

Contreras J.E., Landaeta M.F., Plaza G., Ojeda F.P., BusTOS C.A. 2013: The contrasting hatching patterns and larval growth of two sympatric clingfishes inferred by otolith microstructure analysis. Mar. Freshwater Res. 64: 157-167.

Cribb T.H., Pichelin S., Dufour V., Bray R.A., Chauvet C., Faliex E., Galzin R., Lo C.M., Lo-Yat A., Morand S., Rigby M.C., SASAL P. 2000: Parasites of recruiting coral fish reef larvae in New Caledonia. Int. J. Parasitol. 30: 1445-1451.

Felley S.M., Vecchione M.L., Hare S.G.F. 1987: Incidence of ectoparasitic copepods on ichthyoplankton. Copeia 3: 778-782.

Filatov D.A. 2002: Proseq: software for preparation and evolutionary analysis of DNA sequence datasets. Mol. Ecol. Notes 2: $621-624$

Flores K., George-Nascimento M. 2009: Las infracomunidades de parásitos de dos especies de Scartichthys (Pisces: Blenniidae) en localidades cercanas del norte de Chile. Rev. Chil. Hist. Nat. 82: 63-71.

Folmer O., Black M., Hoeh W., Lutz R., Vrijenhoek R. 1994 DNA primers for amplification of mitochondrial cytochrome c-oxidase subunit I from diverse metazoan invertebrates. Mol. Mar. Biol. Biotech. 3: 294-299.

George-Nascimento M. 1996: Populations and assemblages of parasites in hake, Merluccius gayi, from southeastern Pacific Ocean: stock implications. J. Fish. Biol. 48: 557-568.

George-Nascimento M., Muñoz G., Marquet A.P., Poulin R. 2004: Testing the energetic equivalence rule with helminth endoparasites of vertebrates. Ecol. Lett. 7: 527-531.
GonzÁLez L. 1998: The life cycle of Hysterothylacium aduncum (Nematoda: Anisakidae) in Chilean marine farms. Aquaculture 162: 173-186.

González L., Carvajal J. 2003: Life cycle of Caligus rogercresseyi (Copepoda: Caligidae) parasite of Chilean reared salmonids. Aquaculture 220: 101-117.

Hebert P., Penton E., Burns J., Janzen D., Hallwachs W. 2004: Ten species in one: DNA barcoding reveals cryptic species in the neotropical skipper butterfly Astraptes fulgerator. Proc. Natl. Acad. Sci. U. S. A. 101: 14812-14817.

Henriquez V., GonzÁlez M.T. 2014: Patterns of variation in parasite component communities and infracommunities of a littoral fish species from the northern coast of Chile. J. Helminthol. 88: 89-96.

Herrera G. 1984: Parasitismo de juveniles de copépodos caligoideos sobre larvas de peces de la Bahía Coliumo (36 32'S; 75 57’W), Chile. Biol. Pesq. 13: 31-38.

HerRERA G. 1990: Incidence of anchovy (Engraulis ringens) larvae parasitized by caligid developmental stages. Bull. Mar. Sci. 47: 571-575.

Herrera G.A., Llanos-Rivera A., Landaeta M.F. 2007: Larvae of the sand stargazer Sindoscopus australis and notes on the development of Dactyloscopidae (Perciformes: Blennioidei). Zootaxa 1401: 63-68.

Ismail N., Ohtsuka S., Venmathi-Maran B.A., Tasumi S., Zaleha K., Yamashita H. 2013: Complete life cycle of a pennellid Peniculus minuticaudae Shiino, 1956 (Copepoda: Siphonostomatoida) infecting cultured threadsail filefish, Stephanolepis cirrhifer. Parasite 20: 42.

Kabata Z. 1979: Parasitic Copepoda of British Fishes. The Ray Society, London, $468 \mathrm{pp}$.

Lacerda A.C.F., Santin M., Takemoto R.M., Pavanelli G.C., Bialetzki A., Tavernari F.C. 2009: Helminths parasitizing larval fish from Pantanal, Brazil. J. Helminthol. 83: 51-55.

Landaeta M.F., Martínez R., Bustos C.A., Castro L.R. 2013: Distribution of microplankton and fish larvae related to sharp clines in a Patagonian fjord. Rev. Biol. Mar. Oceanogr. 48: 401-407.

Larkin M.A., Blackshields G., Brown N.P., Chenna R., McGettigan P.A., McWilliam H., Valentin F., Wallace I.M., Wilm A., Lopez R., Thompson J.D., Gibson T.J., HigGINS D.G. 2007: Clustal W and Clustal X version 2.0. Bioinformatics 3: 2947-2948.

MaCKenZIE K. 1974: Immature digeneans from the alimentary tract of larval and juvenile pelagic stages of haddock, Melanogrammus aeglefinus (L.). J. Fish Biol. 6: 103-106.

Madinabeitia I., Nagasawa K. 2011: Chalimus stages of Caligus latigenitalis (Copepoda: Caligidae) parasitic on blackhead seabream from Japanese waters, with discussion of terminology used for developmental stages of caligids. J. Parasitol. 97: 221-236.

Morais-Falavigna D.L., Machado Velho L.F., Pavanelli G.C. 2003: Proteocephalidean larvae (Cestoda) in naturally infected cyclopid copepods of the Upper Paraná River Floodplain, Brazil. Mem. Inst. Oswaldo Cruz 98: 69-72.

Morales-Serna F.N., Hernández-Inda Z.L., Gómez S., PéREZ-PONCE DE LEÓN G. 2013: Redescription of Caligus serratus Shiino, 1965 (Copepoda: Caligidae) parasitic on eleven fish species from Chamela Bay in the Mexican Pacific. Acta Parasitol. 58: 367-375.

Moyano M., Rodríguez J. M., Hernández-León S. 2009: Larval fish abundance and distribution during the late winter bloom 
off Gran Canaria Island, Canary Islands. Fish. Oceanogr. 18: $51-61$.

MuÑoz G. 2014: Parasite communities in the clingfish Gobiesox marmoratus from central Chile. Acta Parasitol. 59: 108-114.

Muñoz G., Castro R. 2012: Comunidades de parásitos eumetazoos de peces labrisómidos de Chile central. Rev. Biol. Mar. Oceanogr. 47: 565-571.

Muñoz G., Delorme N. 2011: Variaciones temporales de las comunidades de parásitos de peces intermareales de Chile central: hospedadores residentes vs temporales. Rev. Biol. Mar. Oceanogr. 46: 313-327.

Muñoz G., Olmos V. 2007: Revisión bibliográfica de especies ectoparásitas y hospedadoras de sistemas acuáticos de Chile. Rev. Biol. Mar. Oceanogr. 42: 89-148.

Muñoz G., Valdebenito V., George-Nascimento M. 2002: La dieta y la fauna de parásitos metazoos del torito Bovichthys chilensis Regan 1914 (Pisces: Bovichthydae) en la costa de Chile centro-sur: variaciones geográficas y ontogenéticas. Rev. Chil. Hist. Nat. 75: 661-671.

Nei M., Kumar S. 2000: Molecular Evolution and Phylogenetics. Oxford University Press, London, $333 \mathrm{pp}$.

Nielson J.D., Perry R.I., Scott J.S., Valerio P. 1987: Interactions of caligid ectoparasites and juvenile gadids on Georges Bank. Mar. Ecol. Prog. Ser. 39: 221-232.

Ochoa-Muñoz M.J., Valenzuela C.P., Toledo S., Bustos C.A., Landaeta M.F. 2013: Feeding of a larval clinid fish in a microtidal estuary from southern Chile. Rev. Biol. Mar. Oceanogr. 48: 45-57.

Oines O., Heuch P.A. 2005: Identification of sea louse species of the genus Caligus using mtDNA. J. Mar. Biol. Assoc. U. K. 85: 73-79.

Oines O., Schram T. 2008: Intra- or inter-specific difference in genotypes of Caligus elongatus Nordmann 1832? Acta Parasitol. 53: 93-105.

Palacios-Fuentes P., Landaeta M.F., Muñoz G., Plaza G., OJEDA F.P. 2012: The effects of a parasitic copepod on the recent larval growth of a fish inhabiting rocky coasts. Parasitol. Res. 111: 1661-1671.

Pardo-Gandarillas M.C., Garcías F., George-Nascimento M. 2004: La dieta y la fauna de endoparásitos del pejesapo Gobiesox marmoratus Jenyns, 1842 (Pisces: Gobiesocidae) en el litoral de Chile están conectadas pero no correlacionadas. Rev. Chil. Hist. Nat. 77: 627-637.

PÉREZ R. 1979: Desarrollo postembrionario de Tripterygion chilensis Cancino 1955, en la Bahía de Valparaíso (Tripterygiidae: Perciformes). Rev. Biol. Mar. 16: 319-329.

PÉREZ R.1981: Desarrollo embrionario y larval de los pejesapos Sicyases sanguineus y Gobiesox marmoratus en la Bahía de Val- paraíso, Chile, con notas sobre su reproducción (Gobiesocidae: Pisces). Inves. Mar. 9: 1-24.

Plaza G., Landaeta M.F., Espinoza C.V., Ojeda F.P. 2013: Daily growth patterns of six species of young-of-the-year of Chilean intertidal fishes. J. Mar. Biol. Assoc. U. K. 93: 389-395.

Posada D., Crandall K.A. 1998: Modeltest: testing the model of DNA substitution. Bioinformatics 1: 817-818.

Radulovici A., Archambault P., Dufresne F. 2010: DNA barcoding for marine biodiversity: moving fast forward? Diversity 2: $450-472$

Riscala-Madi R.; Tiduko-Ueta M., Ferraz-Frezza T., Müller M.I., Bazan-Simionatto K. 2011: Copépodos Notodiaptomus sp. Kiefer (Crustacea, Calanoida) naturalmente infectados com metacestódeos no reservatório do Juqueri, São Paulo, Brasil. Biota Neotrop. 11: 179-182.

Rosenthal H. 1967: Parasites in larvae of the herring (Clupea harengus L.) fed with wild plankton. Mar. Biol. 1: 10-15.

RusineK O.T., BAKINA M.P., NiKOLSKII A.V. 1996: Natural infection of the calanoid crustacean Epischura baicalensis by procercoids of Proteocephalus sp. in Listvenichnyi Bay, Lake Baikal. J. Helminthol. 70: 237-247.

Sirois P., Dobson J.J. 2000: Influence of turbidity, food density and parasites on the ingestion and growth of larval rainbow smelt Osmerus mordax. Mar. Ecol. Prog. Ser. 193: 167-179.

Skovgaard A., Bahlool Q.M.S., Munk P., Bege T., BuchMANN K. 2011: Infection of North Sea cod, Gadus morhua L., larvae with the parasitic nematode Hysterothylacium aduncum Rudolphi. J. Plankton Res. 33: 1311-1316.

Song Y., Wang G.T., Yao W.J., Gao Q., Nie P. 2008: Phylogeny of freshwater parasitic copepods in the Ergasilidae (Copepoda: Poecilostomatoida) based on $18 \mathrm{~S}$ and $28 \mathrm{~S}$ rDNA sequences. Parasitol. Res. 102: 299-306.

Sutherland K., Strydom N.A., Wooldridge T.H. 2012: Composition, abundance, distribution and seasonality of larval fishes in the Sundays Estuary, South Africa. Afr. Zool. 47: 229-244.

Swofford D.L. 2001: PAUP: Phylogenetic Analysis Using Parsimony (*and other methods). ver. 4.0b8. Sinauer, Sunderland, M.A.

Tamura K., Nei M. 1993: Estimation of the number of nucleotide substitutions in the control region of mitochondrial DNA in humans and chimpanzees. Mol. Biol. Evol. 10: 512-526.

Tamura K., Stecher G., Peterson D., Filipski A., Kumar S. 2013: MEGA6: Molecular Evolutionary Genetics Analysis Version 6.0. Mol. Biol. Evol. 30: 2725-2729.

Venmathi-Maran B.A., Moon S.Y., Оhtsuka S., Oh S-Y., Soh H.Y., Myoung J-G., IglikowsKa A., Boxshall G.A. 2013: The caligid life cycle: new evidence from Lepeophtheirus elegans reconciles the cycles of Caligus and Lepeophtheirus (Copepoda: Caligidae). Parasite 20: 15. 